\title{
Three new species of the genus Stephos Scott, 1892 (Crustacea, Copepoda, Calanoida, Stephidae) from Jeju Island, Korea
}

\author{
Seong Yong Moon', Ho Young Soh², Dae Hyun $\mathrm{Cho}^{3}$ \\ I South Sea Fisheries Research Institute, National Institute of Fisheries Science, Yeosu 59780, South Korea \\ 2 Department of Environmental Oceanography, Chonnam National University, Yeosu 596166, South Korea \\ 3 Department of Oceanography, Chonnam National University, Gwangju 61186, South Korea
}

Corresponding author: Seong Yong Moon (msy7744@korea.kr)

Academic editor: D. Defaye | Received 15 December 2019 | Accepted 1 April 2020 | Published 30 June 2020

http://zoobank.org/48DC6479-DFA3-433F-98B5-D79097B3AA32

Citation: Moon SY, Soh HY, Cho DH (2020) Three new species of the genus Stephos Scott, 1892 (Crustacea, Copepoda, Calanoida, Stephidae) from Jeju Island, Korea. ZooKeys 944: 1-30. https://doi.org/10.3897/zookeys.944.49361

\begin{abstract}
During general field surveys carried out recently to collect benthopelagic copepods from near the substrate of the shallow waters off Jeju Island, Korea, a few specimens of three new species of Stephos Scott, 1892, were collected. The new species are placed in the genus Stephos because of the following combination of features: absence of seta on the basal exite of maxillule, and male right leg 5 ending in an unarmed clawlike and/or mitten-like segment. Stephos jejuensis sp. nov. can be distinguished from its congeners by body length $0.92 \mathrm{~mm}$, left side of the female genital double-somite with protruding lobes, antennule that extends beyond the distal area of the genital double-somite, and the male leg 5 terminal complex. Stephos concavus sp. nov. can be distinguished from its congeners by the genital double-somite with protruding lobes on both sides, and the presence of larger spinules on the distomedial margin of leg 5. Stephos fortipes sp. nov. can be distinguished from its congeners by its longer body length, $1.12 \mathrm{~mm}$ long in the female, antennules that extend to the end of the genital double-somite, and the presence of a covered row of minute spinules on the ventral surface of the genital operculum in the female. Until now, 35 species of stephids were known worldwide.
\end{abstract}

\section{Keywords}

Stephos, new species, benthopelagic, near bottom, Jeju Island

Copyright Seong Yong Moon et al. This is an open access article distributed under the terms of the Creative Commons Attribution License (CC BY 4.0), which permits unrestricted use, distribution, and reproduction in any medium, provided the original author and source are credited. 


\section{Introduction}

Benthopelagic copepods are of low abundance and high diversity in the benthic boundary layer (Bradford-Grieve 2004). However, they are difficult to sample on the continental slope or ocean-basin environments, which has contributed to the slow accumulation of knowledge about the benthopelagic fauna (Bradford-Grieve 2004). The benthopelagic calanoid family Stephidae Sars, 1902, consists of four valid genera by: Stephos Scott, 1892; Parastephos Sars, 1902; Miostephos Bowman, 1976 and Parastephos Sars, 1902; Speleohvarella Kršinić, 2005. Their species are generally smaller in body size, and include hyperbenthic forms living in anchialine and marine coastal habitats (Boxshall and Halsey 2004; Jaume et al. 2008; Kršinic 2012, 2015; Moon et al. 2015; Suárez-Morales et al. 2017). The genus Stephos is the most diverse, comprising 32 species (Bradford-Grieve 1999; Boxshall and Halsey 2004; Kršinić 2015; Moon et al. 2015; Suárez-Morales et al. 2017). Up to now, there have been a total of eleven species from the Australia-Western Pacific region, as follows: S. pentacanthos Chen \& Zhang, 1965; S. morii Greenwood, 1978; S. tropicus Mori, 1942; S. tsuyazakiensis Tanaka, 1967, S. pacificus Ohtsuka \& Hiromi, 1987; S. angulatus Bradford-Grieve, 1999; S. robustus Ohtsuka \& Hiromi, 1987; S. kurilensis Kos, 1972; S. hastatus Bradford-Grieve, 1999; S. geojinensis Moon, Youn \& Venmathi Maran, 2015; and S. projectus Moon, Youn \& Venmathi Maran, 2015. Species of Stephos show many similarities to species of its confamilial genera but differs as follows: the male right fifth leg is 4-segmented (vs. 5-segmented in Parastephos and 3-segmented in Miostephos and Speleohvarella); and the male right fifth leg ends in an unarmed claw-like and/or mitten-like segment (vs. a claw being armed with spines along the concave margin in Parastephos and reduced in Miostephos and Speleohvarella) (Boxshall and Halsey 2004). The zoogeographical distribution of species of Stephos was established by Suárez-Morales et al. (2017).

During a survey of the copepod fauna of the southern coasts of Jeju Island, the largest island in Korea, a few specimens of stephids were collected from near-bottom shallow waters by vertical tows of $0.1-\mathrm{mm}$ mesh conical nets at high tide in dusk hours. One of these samples contained representatives of several Stephos not known to the benthopelagic environment. This paper reports on three undescribed species of the genus Stephos that are herein described in full and compared with their known congeners around the world.

\section{Materials and methods}

Copepods were collected from the shallow waters of Jeju Island, Korea by vertical tows (0.1-mm mesh conical nets) at high tide in dusk hours (Fig. 1). For morphological examination, samples were fixed in a 5\% natural formalin-seawater solution and cleared in $70 \%$ lactic acid for an hour before dissection in a drop of lactophenol on a wooden slide under the dissection microscope (Humes and Gooding 1964). Dissected body parts and appendages were examined under a compound microscope with magnification up to X1,000. Measurements were made with a stage micrometer from the head 


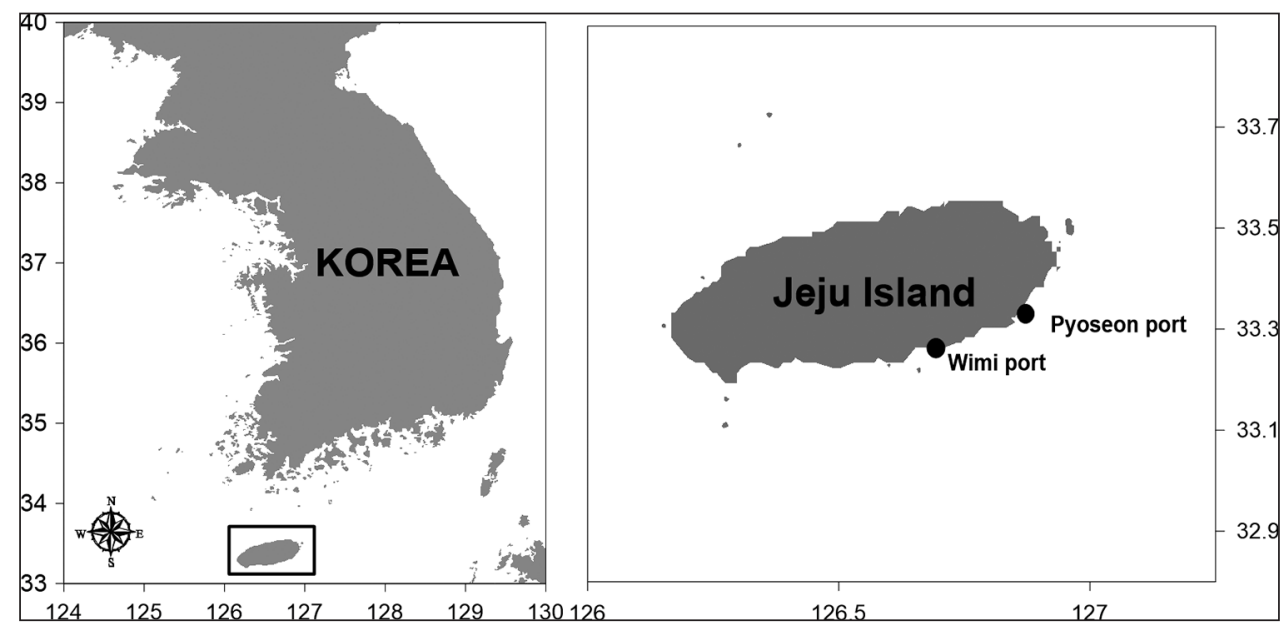

Figure I. Map showing the sampling location (black circles) in Jeju Island, Korea.

to the tip of the caudal ramous, excluding the caudal setae. Drawings were made with the aid of a drawing tube equipped on the microscope. The morphological terminology follows Huys and Boxshall (1991) and Ferrari and Ivanenko (2008). An abbreviation used in the text and figures is ae, for aesthetasc. Specimens are deposited at the National Institute of Biological Resources (NIBR), Incheon, Korea.

\section{Taxonomy}

Order Calanoida Sars, 1901

Family Stephidae Sars, 1902

Genus Stephos Scott, 1892

\section{Stephos jejuensis sp. nov.}

http://zoobank.org/94A56606-DD69-43B6-9EB0-F6ED232AF163

Figures 2-5

Material examined. Holotype $q$ (NIBRIV0000840220), allotype $\delta$ (NIBRIV0000840219) undissected in 70\% ethanol, 11 November 2012. Dissected paratypes + (NIBRIV0000840221), ô (NIBRIV0000840222) mounted on two glass slides, 11 November 2011. All specimens collected by D. H. Cho.

Type locality. Near the bottom (ca. $5 \mathrm{~m}$ depth), Pyoseon port, Jeju Island $\left(33^{\circ} 19^{\prime} 32 " \mathrm{~N}, 126^{\circ} 50^{\prime} 42 " \mathrm{E}\right)$, Korea.

Etymology. The specific name of the new species jejuensis refers to the type locality.

Description of female. Body (Fig. 2A, B) robust, length $0.92 \mathrm{~mm}$ (mean $0.91 \pm$ $0.03, N=3$ ). Prosome 5-segmented; cephalosome and first pedigerous somites completely separated; fourth and fifth pedigerous somites incompletely fused (Fig. 2A, B), 


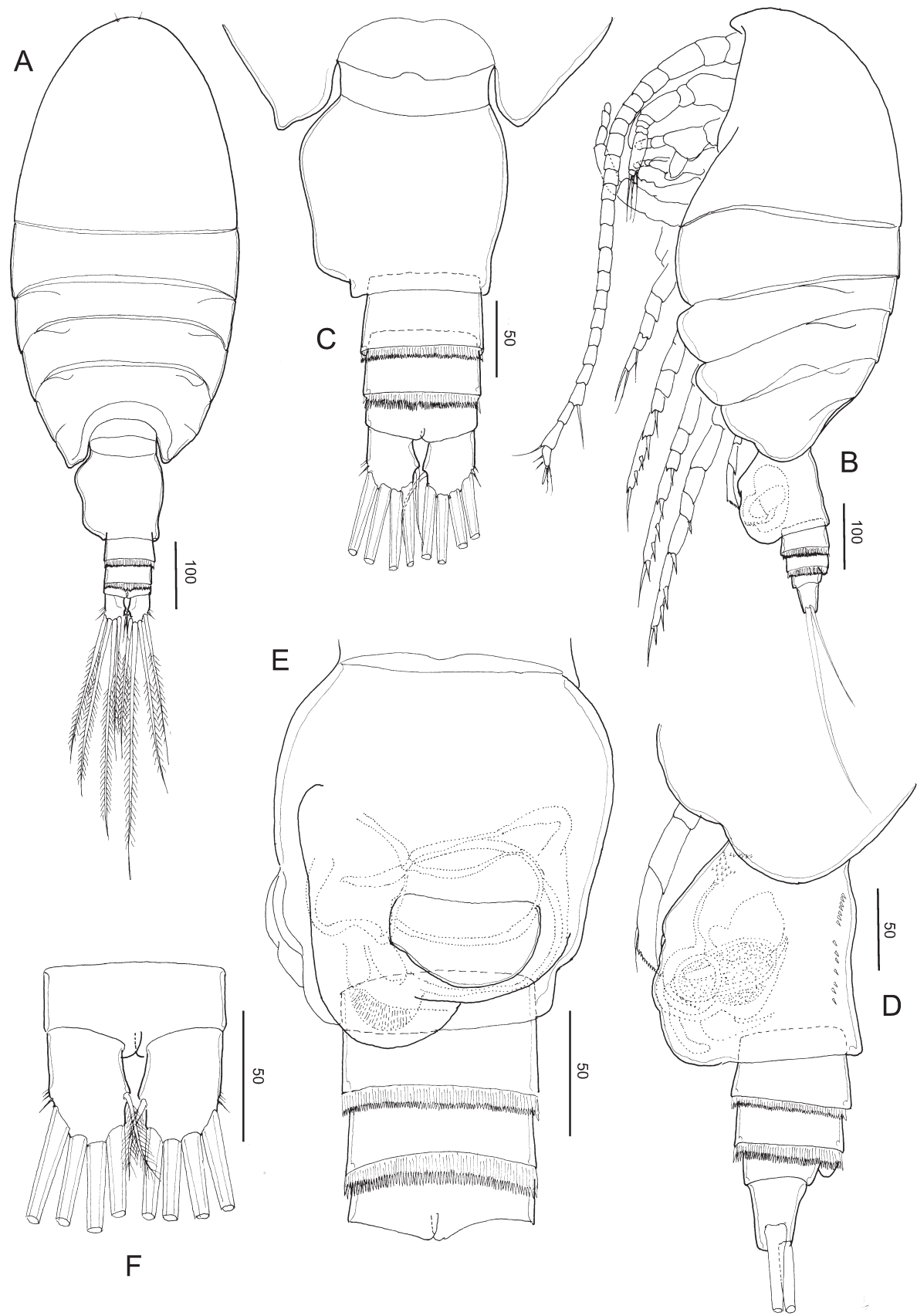

Figure 2. Stephos jejuensis sp. nov. Female paratype $\mathbf{A}$ habitus, dorsal view $\mathbf{B}$ habitus, lateral view $\mathbf{C}$ urosome, dorsal view $\mathbf{D}$ urosome, lateral view $\mathbf{E}$ urosome, ventral view $\mathbf{F}$ anal somite and caudal rami. Scale bars in $\mu \mathrm{m}$. 
posterior corners of fifth pedigerous somite slightly asymmetric. Rostrum represented by a rounded knob. Prosome-urosome ratio 2.61:1. Urosome 4-segmented, comprising genital double-somite, two free abdominal somites, and anal somite; length ratio of genital double-somite, first free abdominal somite, second free abdominal somite, and anal somite as 48.2: 14.2: 12.6:11.7:13.4 = 100. Genital double-somite (Fig. 2C, E) asymmetric, with protruding lobe on the anterior to posterior of the left side and a projecting lobe to distal margin, with minute spinules patched in lateral view (Fig. 2D); on the right anterior side is a swollen, common operculum bumpy-shaped ventromedially and with ear lobe on the ventrolateral margin. First and second abdominal somites with transverse hyaline frill dorsally and ventrally. Anal somite short. Caudal rami (Fig. 2F), with six setae, symmetric, 1.45 times longer than wide $(44 \times 31 \mu \mathrm{m})$; caudal setae II-VII present (seta I lacking); seta II spiniform, seta III ca. half the length of seta $\mathrm{V}$, seta $\mathrm{V}$ longer (right longer than left) than seta IV, both plumose; dorsal seta VII short, plumose.

Antennule (Fig. 3A) symmetric, extending beyond the distal area of genital double-somite; 24-segmented, apparently ancestral. Segments I-II, III-IV, X-XI, and XXVII-XXVIII are fused. Segmentation and setation pattern as follows (ancestral segment number-setae+aesthetasc): I-II-3+2ae, III-IV-4+3ae, V-2+ae, VI-2, VII-2+ae, VIII2+ae, IX-2, X-XI-4+ae, XII-1, XIII-1, XIV-2+ae, XV-1, XVI-2+ae, XVII-1, XVIII-1, XIX-1, XX-1, XXI-1+ae, XXII-1, XXIII-1+ae, XXIV-1+1, XXV-1+1, XXVI-1+1, XXVII-XXVIII-5+ae. Ancestral segments I to XIV and XVI to XXV with a row of spinules on the posterior surface.

Antenna (Fig. 3B) biramous; coxa and basis separate, coxa with one and basis with two setae; endopod 2-segmented, proximal segment with two setae, compound distal segment bilobed with eight and seven plumose setae subterminally and terminally, respectively, outer margin ornamented with small serrated process subdistally on the medial margin; tiny spinule adjacent to serrated process; exopod 7-segmented, with intersegmental articulation between segments 2 and 3 not completely expressed, with setal formula of $1,3,1,1,1,1,3$.

Mandible (Fig. 3C): well-developed coxal gnathobase, with a straight row of moderately incised teeth. Mandibular palp biramous; basis with four setae on the inner margin. Exopod 5-segmented, with setal formula of 1, 1, 1, 1, 2; endopod 2-segmented, proximal with four setae and distal segments with ten setae.

Maxillule (Fig. 3D): praecoxal arthrite bearing nine stout marginal spines and four elements on posterior surface, rows of tiny spinules on the posterior surface. Coxal epipodite with nine setae; coxal endite with three stiff setae. Basis with cluster of denticles on the anterior surface; proximal basal endite with four setae; distal basal endite indistinct, with five setae; no trace of basal exite. Exopod with eleven marginal setae and a row of setules along the distal portion of the medial margin. Endopod not articulated to basis, indistinctly 3-segmented, setal formula 4, 4, 7.

Maxilla (Fig. 3E): apparently 6-segmented, comprising coalesced praecoxa and coxa, allobasis and 3-segmented endopod. Armature of praecoxal and coxal endites 


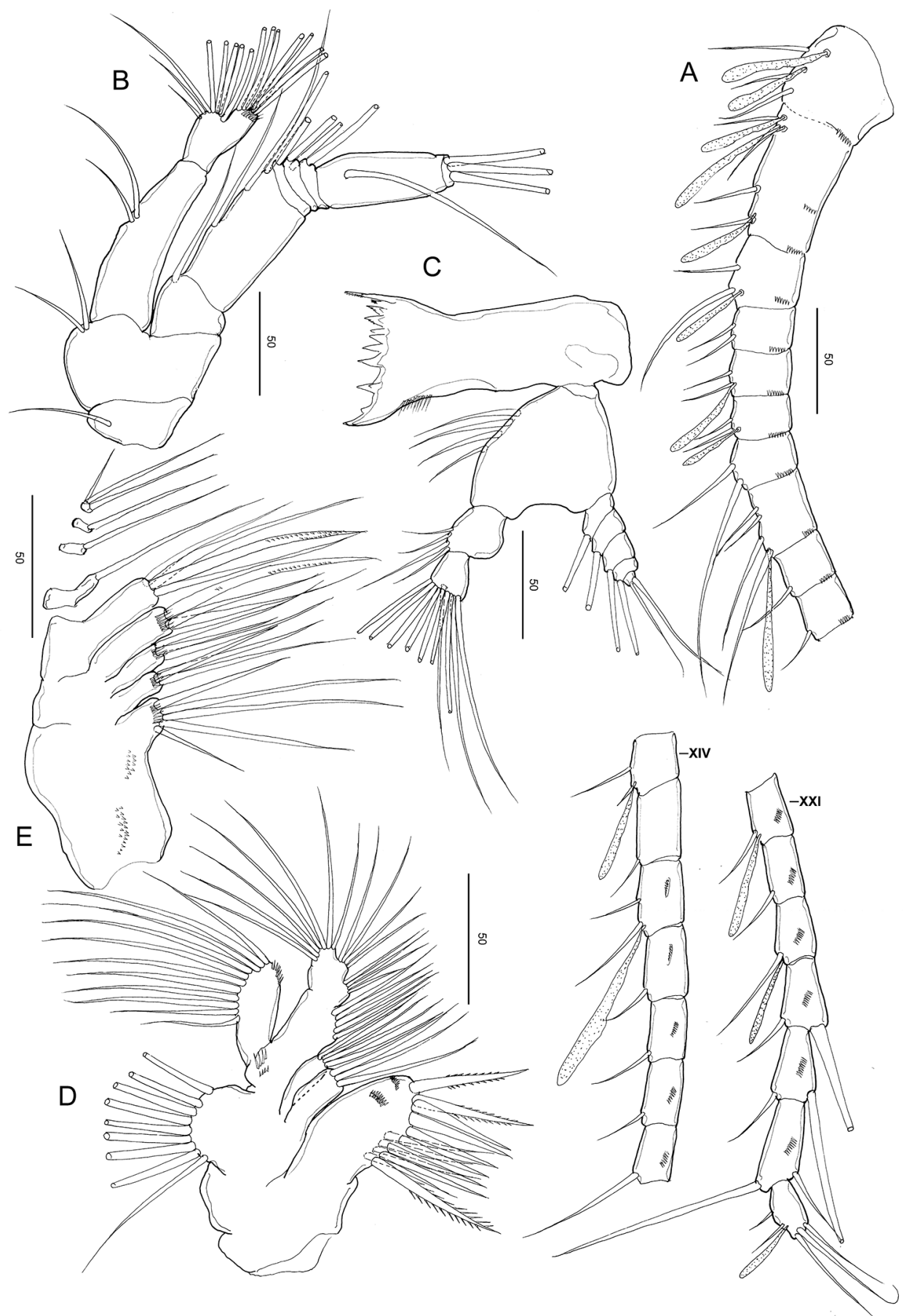

Figure 3. Stephos jejuensis sp. nov. Female paratype $\mathbf{A}$ antennule $\mathbf{B}$ antenna $\mathbf{C}$ mandible $\mathbf{D}$ maxillule E maxilla. Scale bars in $\mu \mathrm{m}$. 
$5,3,3,3$. Basal endite with four setae, one stouter than the rest; endopodal endite with one seta on tip. Free endopod setal formula 1, 1, 3 respectively. Integument of praecoxa ornamented with patch of spinules on the posterior margin. Praecoxal and coxal endites with cluster of long spinules subdistally on the lateral surface; distal coxal endite with additional row of spinules proximally on the medial surface.

Maxilliped (Fig. 4A): syncoxa robust, with setal formula 1, 2, 2, 3 and oblique row of tiny spinules on the posterior distal part; basis with three setae and a row of setules on the mediolateral margin; endopod 6-segmented, with setal formula 2, 4, 4, 3, 3+1, 4 .

Legs 1-4 (Fig. 4B-E) progressively larger toward the posterior, each comprising coxa, basis, and 3-segmented exopod; endopod of leg 1 (Fig. 4B) 1-segmented, that of leg 2 (Fig. 4C) 2-segmented; endopods of P3 (Fig. 4D) and leg 4 (Fig. 4E) 3-segmented. Armature formula of legs $1-4$ as follows (Roman numerals indicate spines, Arabic numeral indicates setae):

\begin{tabular}{lcccc}
\hline \multicolumn{1}{c}{ Legs } & Coxa & Basis & Exopod & Endopod \\
\hline Leg 1 & $0-0$ & $0-1$ & $0-0 ;$ I- $1 ;$ I, 1,3 & $0,2,3$ \\
Leg 2 & $0-1$ & $0-0$ & I-1; I-1; III,I,4 & $0-1 ; 1,2,2$ \\
Legs 3 and 4 & $0-1$ & $0-0$ & I-1; I-1; III,I,4 & $0-1 ; 1,2,2$ \\
\hline
\end{tabular}

Leg 1 (Fig. 4B) biramous, with long curved inner setae on the basis, and endopod with lobe on the outer margin, bearing a minute spinous process and a row of minute spinules on the anterior surface.

Leg 2 (Fig. 4C) biramous, endopod 2-segmented; coxa and basis unarmed; second endopodal segments with a row of spinules on the medial and distal edges, with a pointed process on the distolateral corner; exopod 3-segmented, with a row of spinules on the medio to distal margins of the distal exopodal segment.

Legs 3 (Fig. 4D) and 4 (Fig. 4E) biramous, with 3-segmented rami: coxa and basis unarmed; second and distal endopodal segments with a row of spinules on the distal edges, with a pointed process on each of the distolateral corners; exopod with a row of spinules on the medial to distal margins of the distal exopodal segment.

Leg 5 (Fig. 4F) symmetric, uniramous, 3-segmented with a proximal segment fused to intercoxal sclerite; basis separated, 2.27 times longer than wide $(41 \times 18 \mu \mathrm{m})$, widening distally with minute spinules on the anterior corner and an acute inner process, and unarmed. Distal segment with a transverse row of spinules across near the middle part and an outer seta medially.

Description of male. Body (Fig. 5A, B) robust, length $0.93 \mathrm{~mm}$. Prosome 5-segmented; cephalosome and first pedigerous somites completely separated; fourth and fifth pedigerous somites incompletely fused (Fig. 5A). Rostrum same as in female. Prosome-urosome ratio 2.18:1. Urosome 5-segmented, comprising genital somite, three free abdominal somites, and anal somite; length ratio of genital somite, first to fourth free abdominal somites, and anal somite as 27.5: 19.2: 16.3: 14.5: 10.9: $11.5=100$. Genital somite with asymmetric and protruding lobe on the left side. First to third ab- 


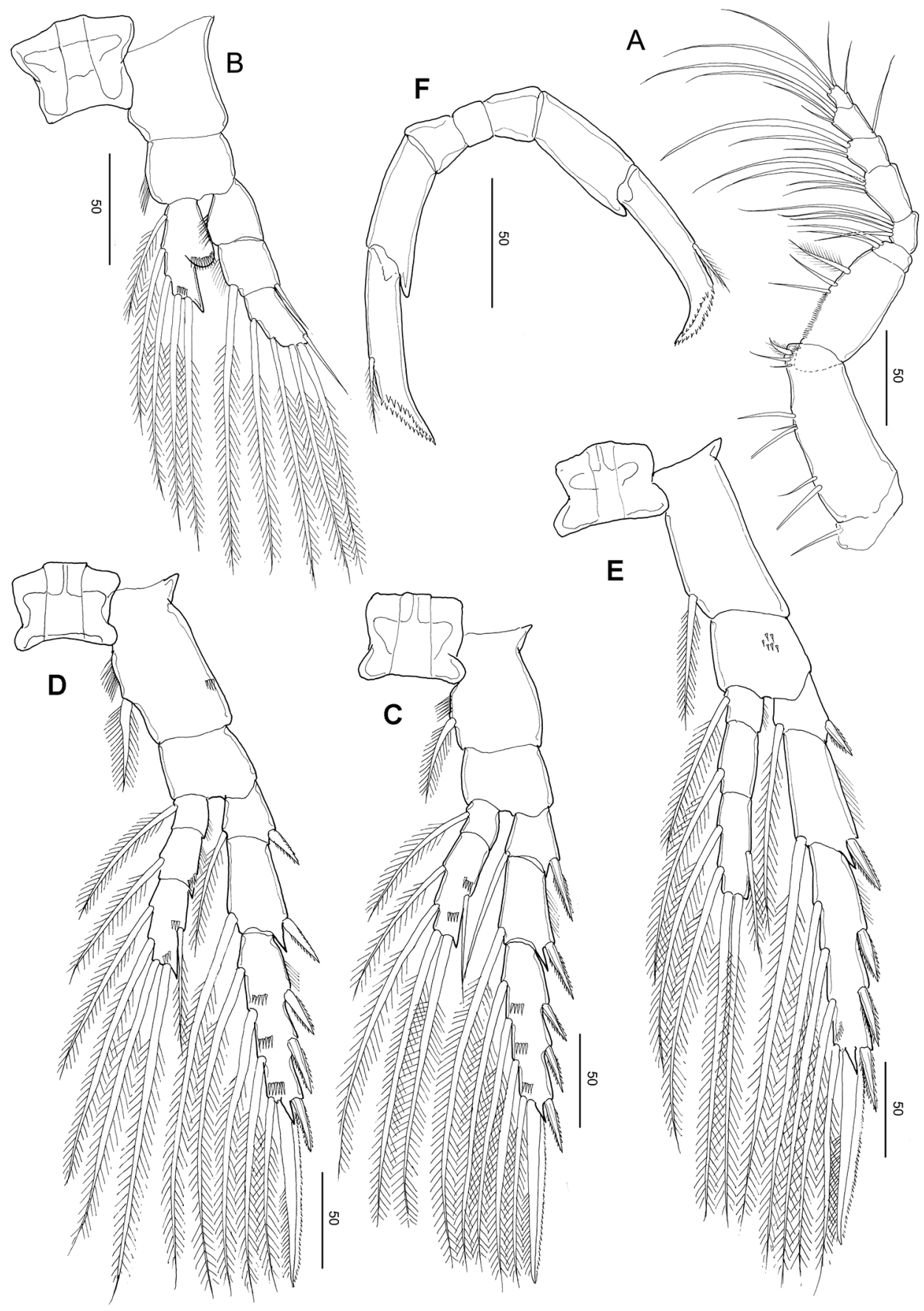

Figure 4. Stephos jejuensis sp. nov. Female paratype A maxilliped B leg 1 C leg 2 D leg 3 E Leg 4 F Leg 5. Scale bars in $\mu \mathrm{m}$. 
dominal somites with transverse hyaline frill dorsally and ventrally. Anal somite shortest. Caudal rami similar to those of the female.

Antennule (Fig. 5C) symmetric, extending beyond the distal area of the genital double-somite; 24-segmented, apparently ancestral; segments I-II, III-IV, X-XI, and XXVII-XXVIII are fused. Segmentation and setation pattern as follows (ancestral segment number-setae+aesthetasc): I-II-3+2ea, III-IV-4+3ae, V-2+ae, VI-2, VII-2+ae, VIII2+ae, IX-2, X-XI-4+ae, XII-1, XIII-1, XIV-2+ae, XV-1, XVI-2+ae, XVII-1, XVIII-1, XIX-1, XX-1, XXI-1+ae, XXII-1, XXIII-1+ae, XXIV-1+1, XXV-1+1, XXVI-1+1, XXVII-XXVIII-5+ae. Ancestral segments I-XIV and XVI-XXV with row of spinules on the posterior surface.

Antenna, mandible, maxillule, maxilla, maxilliped and legs 1-4 similar to those of the female.

Leg 5 (Fig. 5D-F), strongly asymmetric, slender on both sides, developed as a grasping organ on the left. Right leg 4-segmented; coxa and basis are short, unarmed, but thickened proximally; terminal segment comprising a single longer process (see arrowed in Fig. 5F), outwardly directed, curved medially, and acute at its tip. Left leg 5-segmented (see Fig. 5E); proximal segment ca. as long as right proximal segment; second segment with rounded outgrowth on medial margin; third segment elongated, unarmed; fourth segment narrow, shorter than third segment; terminal segment complex, with 5 terminal (long) and 5 subterminal (short) lamella spines.

Variations. Within this new species, there was a minor variation in the number of spinules on the genital double-somite and on the surfaces of legs 1-4 in both sexes.

Remarks. The genital double-somite in most species of Stephos has been found to be symmetric and/or slightly asymmetric in shape. The feature of an asymmetric genital somite in S. jejuensis sp. nov. is shared with five of its congeners, S. lamellatus Sars, 1902; S. tsuyazakiensis Tanaka, 1966; S. exumensis Fosshagen, 1970; S. kurilensis Kos, 1972; and S. robustus Ohtsuka \& Hiromi, 1987. Of these, S. jejuensis has a projecting lobe on the distal margin in the lateral side of the genital double-somite; however, the other five species do not have this feature. Stephos jejuensis has been group IV.

In addition, $S$. jejuensis expresses by two diagnostic features: the fifth pedigerous somite is slightly asymmetric; and a projecting lobe in the lateral side of the genital double-somite. These features are shared by only one other species: S. jejuensis can be distinguished from S. maculosus (Bradford-Grieve 1999) by the following features in the female: the body length is $0.92 \mathrm{~mm}$ (vs. $0.62 \mathrm{~mm}$ in $S$. maculosus); dorsally the left side of the genital double-somite has anterior and posterior protruding lobes (vs. without protruding lobe in $S$. maculosus); the antennule extends beyond the distal area of the genital double-somite (vs. not beyond the distal area in S. maculosus); and the distal segment is less than four times longer than the second segment of leg 5 (vs. more than four times in $S$. maculosus). In the male: the body length is $0.93 \mathrm{~mm}$ (vs. $0.54 \mathrm{~mm}$ in $S$. maculosus); the antennule extends beyond the distal area of the genital double-somite (vs. beyond the anterior margin of the caudal rami in S. maculosus); on the leg 5 fourth 


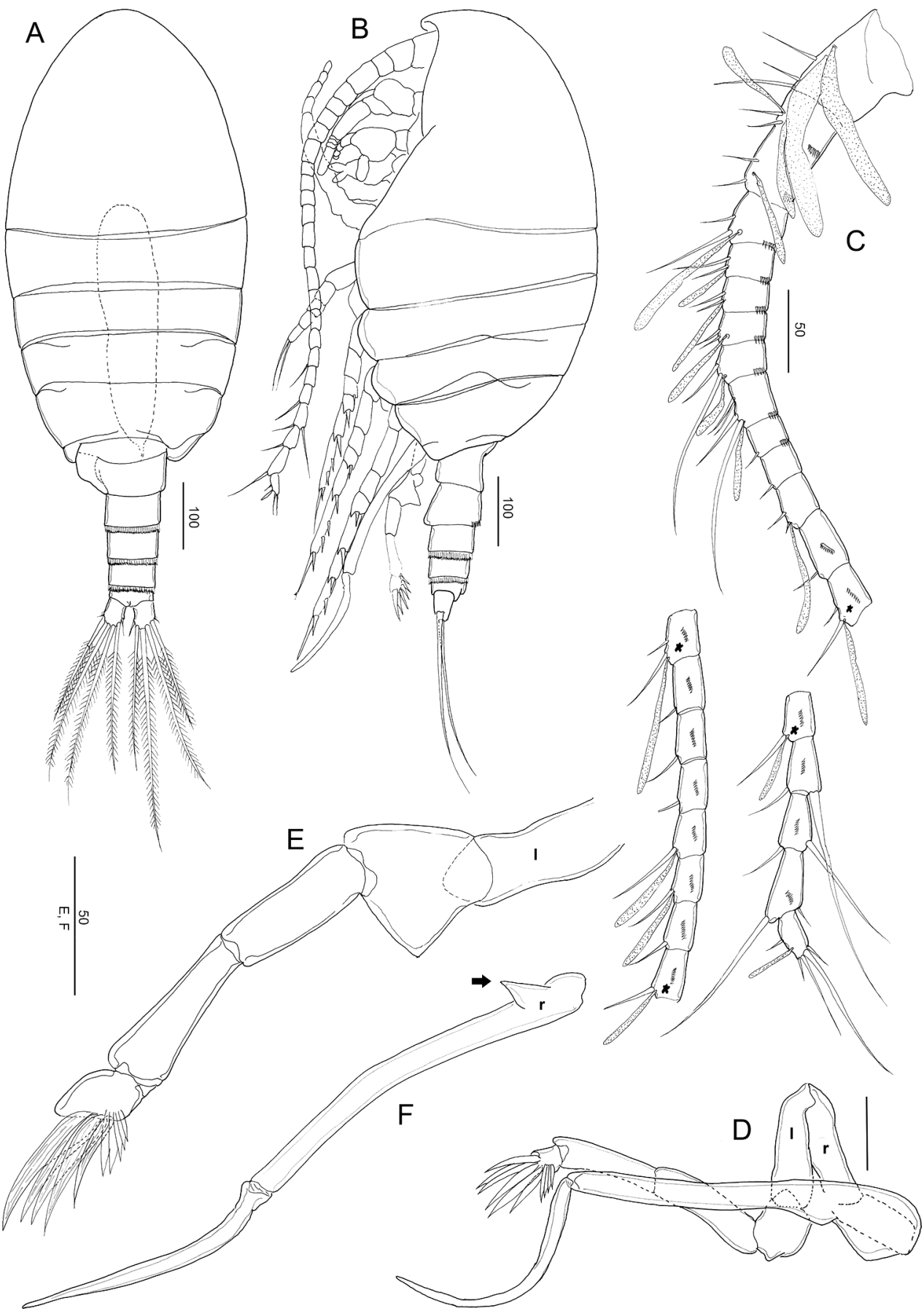

Figure 5. Stephos jejuensis sp. nov. Male paratype $\mathbf{A}$ habitus, dorsal view $\mathbf{B}$ habitus, lateral view $\mathbf{C}$ antennule D-F leg 5. Scale bars in $\mu \mathrm{m}$. 
segment of the male is narrow (vs. with an finger-like lobe on the medial expansion in S. maculosus); and the leg 5 terminal segment complex consists of five terminal (long) and five subterminal (short) lamella spines (vs. not complex, only with three lamella spines in in S. maculosus).

\section{Stephos concavus sp. nov.}

http://zoobank.org/812ECEFE-53ED-4675-90C9-D631F3D40F0C

Figures 6-8

Material examined. Holotype $q$ (NIBRIV0000293109) dissected on two glass slides collected by D. H. Cho, 9 May 2012.

Type locality. Near the bottom (ca. $4 \mathrm{~m}$ depth), Wimi port, Jeju Island (approximately $\left.33^{\circ} 16^{\prime} 13^{\prime \prime} \mathrm{N}, 126^{\circ} 39^{\prime} 43^{\prime \prime} \mathrm{E}\right)$, Korea.

Description of female. Body (Fig. 6A, B) robust, length $0.93 \mathrm{~mm}$. Prosome 5-segmented; cephalosome and first pedigerous somites completely separated; fourth and fifth pedigerous somites incompletely fused (Fig. 6A), posterior corners of prosome slightly asymmetric. Rostrum represented by a rounded knob. Prosome-urosome ratio 2.25:1. Urosome 4-segmented, comprising genital double-somite, two free abdominal somites, and anal somite; length ratio of genital double-somite, first free abdominal somite, second free abdominal somite, and anal somite as 43.0: 18.9:18.1:9.4:10.7 = 100. Genital double-somite (Fig. 6C-E) slightly asymmetric, with protruding lobe on the anterior to medial part of both sides and with a row of spinules in lateral view (Fig. 6C, D); common operculum located ventromedially slightly round (Fig. 6E) and with spermatophore and coupler in dorsal view (Fig. 6C). First and second abdominal somites (Fig. 6C), with transverse hyaline frill dorsally and ventrally. Anal somite shortest. Caudal rami with six setae, symmetric, 1.75 times longer than wide $(49 \times 28 \mu \mathrm{m})$; caudal setae II-VII present (seta I lacking); seta II spiniform, seta III ca. half the length of seta $\mathrm{V}$, seta V longer (right longer than left) than seta IV, both plumose; dorsal seta VII short, plumose.

Antennule (Fig. 7A) symmetric, extending beyond distal area of genital doublesomite; 24-segmented, apparently ancestral, segments I-II, III-IV, X-XI, and XXVII-XXVIII are fused. Segmentation and setation pattern as follows (ancestral segment number-setae+aesthetasc): I-II-3+2ae, III-IV-4+3ae, V-2+ae, VI-2, VII-2+ae, VIII2+ae, IX-2, X-XI-4+ae, XII-1, XIII-1, XIV-2+ae, XV-1, XVI-2+ae, XVII-1, XVIII-1, XIX-1, XX-1, XXI-2+ae, XXII-1, XXIII-1+ae, XXIV-1+1+ae, XXV-1+1, XXVI$1+1$, XXVII-XXVIII-5+ae. Ancestral segments I-XIV and XVI-XXV with row of spinules on posterior surface.

Antenna (Fig. 7B) biramous; coxa and basis separate, coxa with one and basis with two setae; endopod 2-segmented, proximal segment with two setae, compound distal segment bilobed with eight and seven plumose setae subterminally and terminally, 

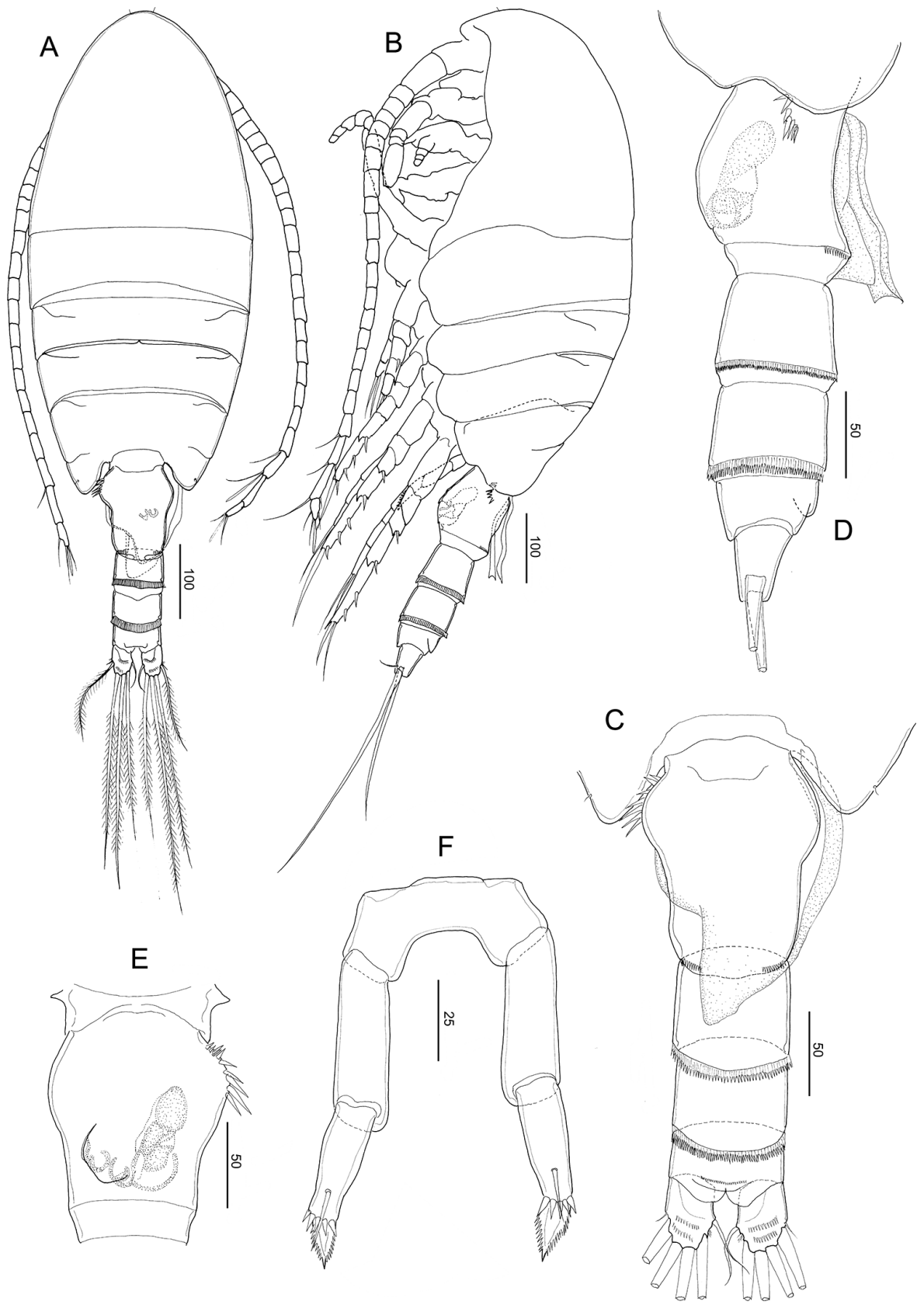

Figure 6. Stephos concavus sp. nov. Female holotype $\mathbf{A}$ habitus, dorsal view B habitus, lateral view $\mathbf{C}$ urosome, dorsal view $\mathbf{D}$ urosome, lateral view $\mathbf{E}$ genital double-somite, ventral $\mathbf{F}$ leg 5. Scale bars in $\mu \mathrm{m}$.

respectively, outer margin ornamented with a small serrated process subdistally on medial margin; tiny spinule adjacent to serrated process; exopod 7-segmented, with intersegmental articulation between segments 2 and 3 not completely expressed, with setal formula of $1,3,1,1,1,1,3$. 


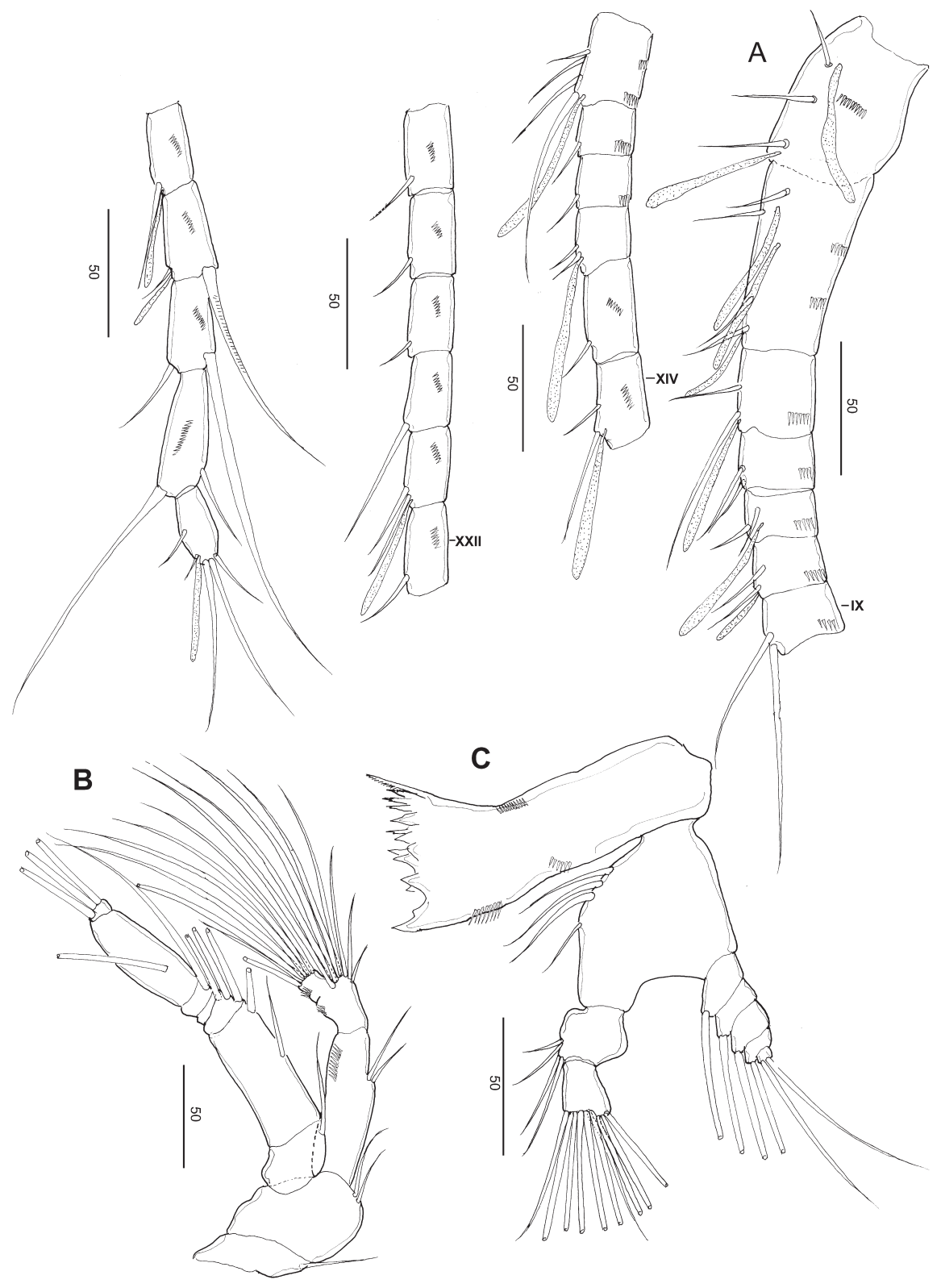

Figure 7. Stephos concavus sp. nov. Female holotype $\mathbf{A}$ antennule B antenna $\mathbf{C}$ mandible. Scale bars in $\mu \mathrm{m}$.

Mandible (Fig. 7C): well-developed coxal gnathobase, with a straight row of moderately incised teeth and patched spinules on the anterior and posterior corners. Mandibular palp biramous; basis with four setae on inner margin. Exopod 5-segmented, with setal formula of 1, 1, 1, 1, 2; endopod 2-segmented, proximal with 4 setae and distal segments with 10 setae. 
Maxillule (Fig. 8A): praecoxal arthrite bearing nine stout marginal spines and four elements on posterior surface, rows of tiny spinules on the posterior surface. Coxal epipodite with nine setae; coxal endite with three stiff setae. Basis with cluster of denticles on the anterior surface; proximal basal endite with four setae; distal basal endite indistinct, with five setae; no trace of basal exite. Exopod with eleven marginal setae; with row of setules along the distal portion of the medial margin. Endopod not articulated to basis, indistinctly 3-segmented, setal formula 4, 4, 7.

Maxilla (Fig. 8B): apparently 6-segmented, comprising coalesced praecoxa and coxa, allobasis, and 3-segmented endopod. Armature of praecoxal and coxal endites 5, $3,3,3$, respectively. Basal endite with four setae, one stouter than the rest; endopodal endite with one seta on tip. Free endopod setal formula 1, 1, 3, respectively. Integument of praecoxa ornamented with a patch of spinules on the posterior margin. Praecoxal and coxal endites with a cluster of long spinules subdistally on the lateral surface; distal coxal endite with an additional row of spinules proximally on the medial surface.

Maxilliped (Fig. 8C): syncoxa robust, with setal formula 1, 2, 2, 3 and an oblique row of tiny spinules on the anterior distal part; basis with three setae and patched setules on the mediolateral margin; endopod 6-segmented, with setal formula 2, 4, 4, 3, 3+1, 4 .

Legs 1-4 (Fig. 8D-G) progressively larger towards the posterior, each comprising coxa, basis, and 3-segmented exopod; endopod of leg 1 (Fig. 8D) 1-segmented, that of leg 2 (Fig. 8E) 2-segmented; endopods of leg 3 (Fig. 8F) and P4 (Fig. 8G) 3-segmented. Armature formula of legs $1-4$ as follows in $S$. jejuensis sp. nov.

Leg 1 (Fig. 8D) biramous, with long curved inner setae on the basis, and endopod with lobe on the outer margin, bearing a minute spinous process and a row of minute spinules on the dorsal surface.

Leg 2 (Fig. 8E) biramous, endopod 2-segmented; coxa and basis unarmed; second endopodal segments with a row of spinules on medial and distal edges, with pointed process on the distolateral corner; exopod 3-segmented, with a row of spinules on the medio to distal margins of the distal exopodal segment.

Legs 3 (Fig. 8F) and 4 (Fig. 8G) biramous, with 3-segmented rami: coxa and basis unarmed; second and distal endopodal segments with a row of spinules on the distal edges, with a pointed process on each distolateral corner; exopod with row of spinules on the medio to distal margins of the distal exopodal segment, except for a row of spinules on the posterior surface of leg 4 basis.

Leg 5 (Fig. 6F) symmetric, uniramous, 3-segmented with a proximal segment fused to intercoxal sclerite; basis separated, 2.53 times longer than wide $(38 \times 15 \mu \mathrm{m})$ and unarmed. Distal segment constricted slightly at ca. mid-length with five large spinules and a large seta medially and with two rows of teeth on both lateral each sides as figured.

Male. Not collected.

Remarks. The new species Stephos concavus sp. nov. is easily recognized by its four diagnostic features in the female: the genital double-somite with a protruding lobe on 


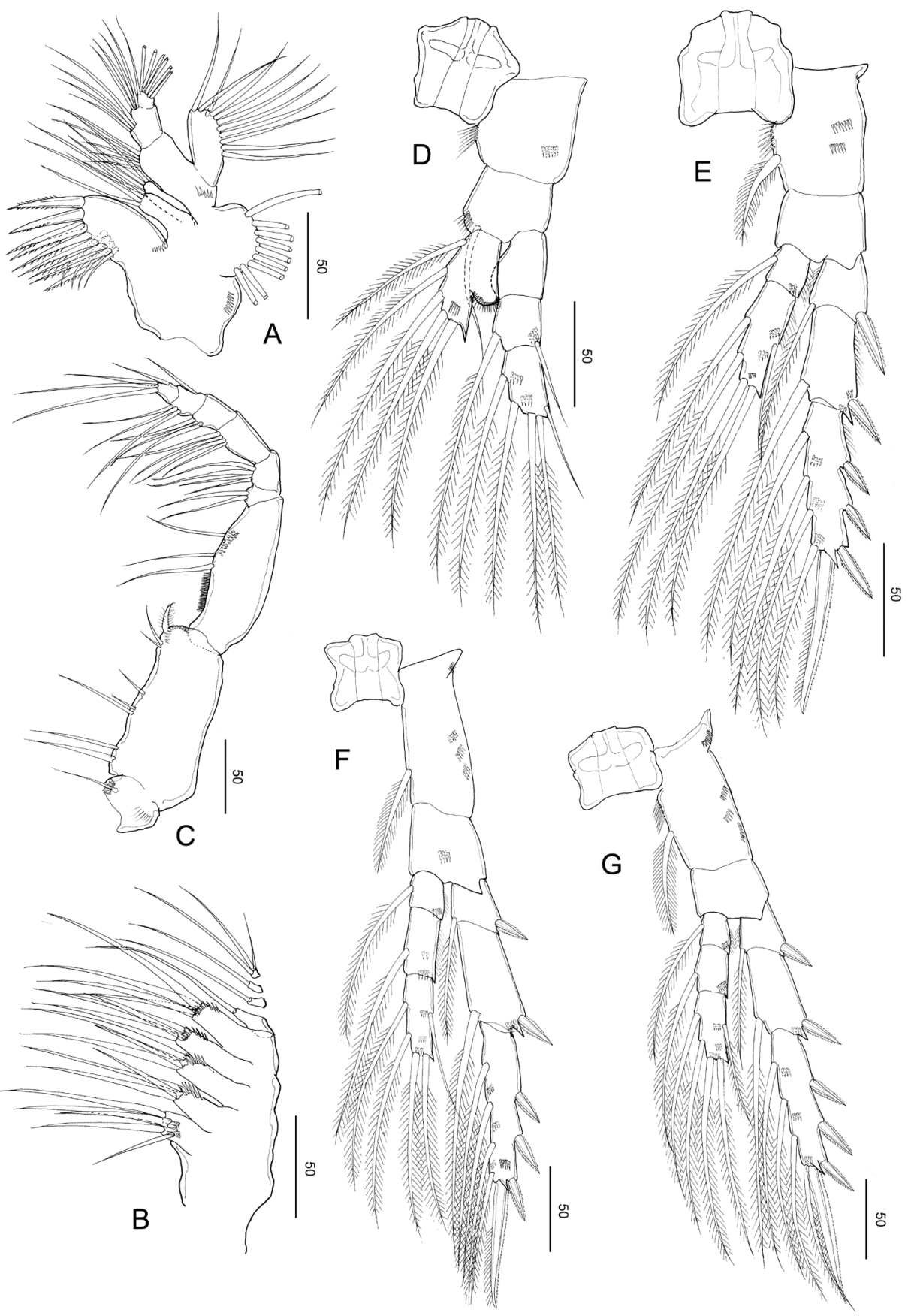

Figure 8. Stephos concavus sp. nov. Female holotype A maxillule B maxilla $\mathbf{C}$ maxilliped $\mathbf{D}$ leg $1 \mathbf{E}$ leg $2 \mathbf{F}$ leg $3 \mathbf{G}$ leg 4 . Scale bars in $\mu \mathrm{m}$. 
the anterior to medial part of both lateral sides; the presence of seven large rows of spinules on the left side of the genital double-somite; the basis of leg 5 is separated, 2.53 times longer than wide; and the presence of large spinules mediodistally on distal segment of leg 5 .

The new species closely resembles S. cryptospinosus (Zagami et al. 2000), but it differs in the following features in the female: the body length is $0.93 \mathrm{~mm}$ (vs. 0.86 $\mathrm{mm}$ in S. cryptospinosus); the presence of seven spinules on the left side of the genital double-somite (vs. absence in S. cryptospinosus); the antennule extends beyond the distal end of the genital double-somite (vs. beyond the posterior margin of the prosome in S. cryptospinosus); the presence of large spinules on the mediodistal margin of leg 5 distal segment (vs. absence in S. cryptospinosus); and the terminal segment with teeth on both sides and large spinules mediodistally on both fifth legs (vs. absence in S. cryptospinosus).

Stephos concavus differs from another congener S. longipes (Giesbrecht, 1902) in the following features of the female: the genital double-somite with protruding lobe on the anterior to medial part of both sides (vs. triangular lobe on the medial part of both sides in S. longipes); the presence of a row of spinules on the left side of the genital double-somite (vs. absence in $S$. longipes); the absence of a row of minute spinules on the dorsodistal surface of the genital double-somite (vs. presence in S. longipes); the leg 5 distal segment is tapering and stout (vs. tapering and not stout in $S$. longipes); and the teeth on the outer margin of both sides (vs. finely serrated fringe on the outer margin in S. longipes).

\section{Stephos fortipes sp. nov.}

http://zoobank.org/C726634A-9A85-4966-B9B1-B63AA83DA929

Figures $9-11$

Material examined. Holotype $q$ (NIBRIV0000293110) dissected on a glass slide collected by D. H. Cho, 9 May 2012.

Type locality. Near the bottom (ca. $4 \mathrm{~m}$ depth), Wimi port, Jeju Island (approximately $\left.33^{\circ} 16^{\prime} 13^{\prime \prime N}, 126^{\circ} 39^{\prime} 43^{\prime \prime} \mathrm{E}\right)$, Korea.

Etymology. The specific name fortipes is the combination of Latin words fortis (strong) and pes (leg), alluding to the strong feature of the female fifth leg.

Description of female. Body (Fig. 9A, B) robust, length $1.12 \mathrm{~mm}$. Prosome fivesegmented; cephalosome and first pedigerous somites completely separated; fourth and fifth pedigerous somites incompletely fused (Fig. 9A), posterior corners of prosome slightly asymmetric. Rostrum represented by a rounded knob. Prosome-urosome ratio 2.45:1. Urosome 4-segmented, comprising a genital double-somite, two free abdominal somites, and anal somite; length ratio of genital double-somite, first free abdominal somite, second free abdominal somite, and anal somite as 39.1: 18.7: 17.1:15.1:10.0 = 100. Genital double-somite (Fig. 9C, E) slightly asymmetric with a differing groups 


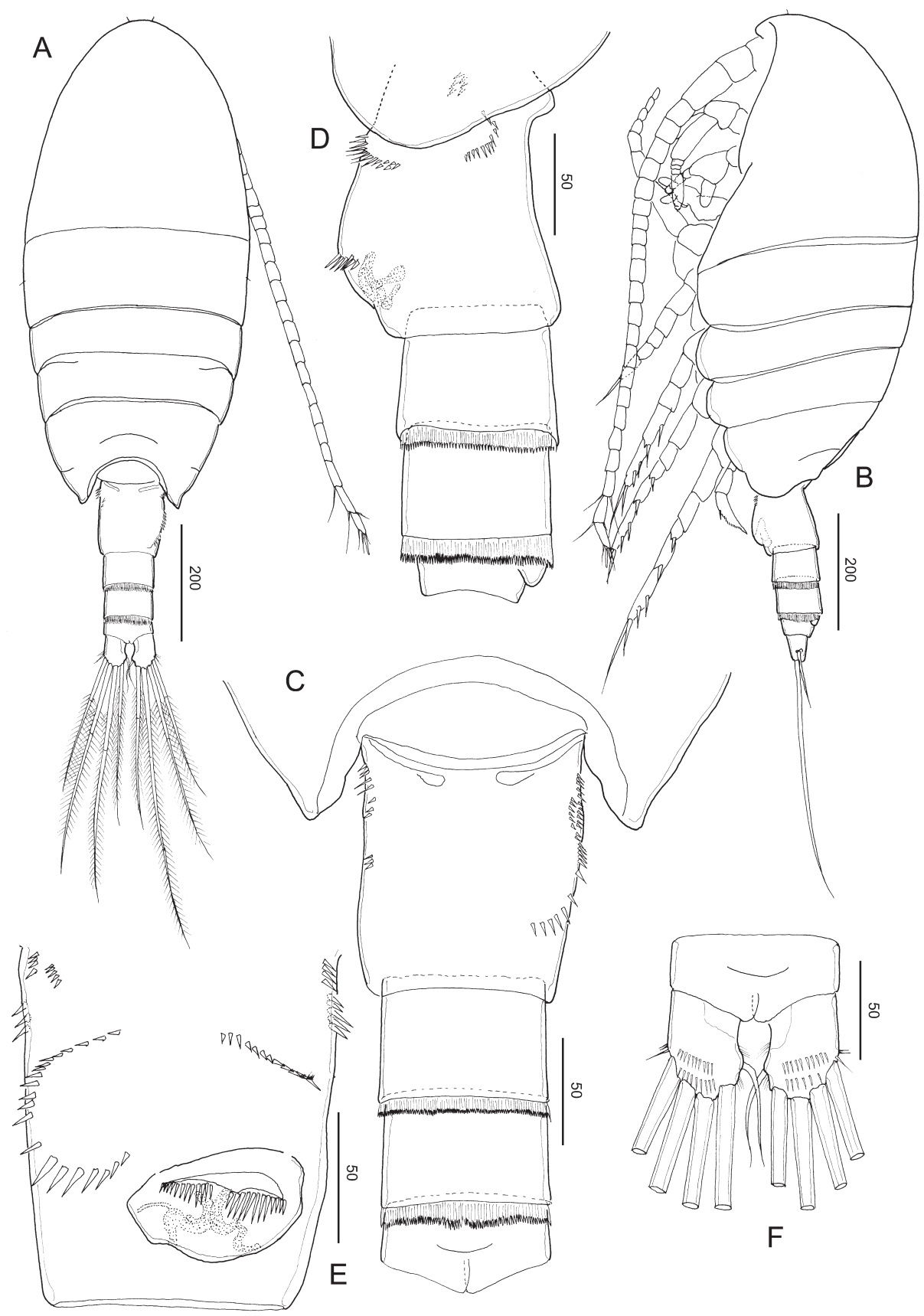

Figure 9. Stephos fortipes sp. nov. Female paratype $\mathbf{A}$ habitus, dorsal view $\mathbf{B}$ habitus, lateral view $\mathbf{C}$ urosome, dorsal view $\mathbf{D}$ urosome, lateral view $\mathbf{E}$ genital double-somite, ventral view $\mathbf{F}$ caudal rami, dorsal view. Scale bars in $\mu \mathrm{m}$. 
of minute spinules on each side, anterior to mid-length; on the left side is a group of minute spinules that tend to be obscured by detritus and difficult to observe, patches and rows of fine spinules on the right side; genital double-somite not produced ventrally, operculum slightly round, with rows of spinules on the ventral surface. First and second abdominal somites (Fig. 9C), with transverse hyaline frill dorsally and ventrally. Anal somite shortest. Caudal rami (Fig. 9F), with six setae, symmetric, 1.19 times longer than wide $(56 \times 47 \mu \mathrm{m})$, with minute spinules on the dorsal surface; caudal setae II to VII present (seta I lacking); seta II spiniform, seta III ca. half the length of seta V, seta V longer (right longer than left) than seta IV, both plumose; dorsal seta VII short, plumose.

Antennule (Fig. 10A) symmetric, extending near to distal area of genital doublesomite; 24-segmented, apparently ancestral, segments I-II, III-IV, X-XI, and XXVIIXXVIII are fused. Segmentation and setation pattern as follows (ancestral segment number-setae+aesthetasc): I-II-3+ae, III-IV-4+3ae, V-2+ae, VI-2, VII-2+ae, VIII2+ae, IX-2, X-XI-4+ae, XII-1, XIII-1, XIV-2+ae, XV-1, XVI-2+ae, XVII-1, XVIII-1, XIX1, XX-1, XXI-1+ae, XXII-1, XXIII-1, XXIV-1+1, XXV-1+1, XXVI-1+1, XXVII-XXVIII-5+ae. Ancestral segments I-XIV and XVI-XXV with a row of spinules on the posterior surface.

Antenna (Fig. 10B) biramous; coxa and basis separate, coxa with one and basis with two setae; endopod 2-segmented, proximal segment with two setae, compound distal segment bilobed with eight and seven plumose setae subterminally and terminally, respectively, outer margin ornamented with a small serrated process subdistally on the medial margin; tiny spinule adjacent to the serrated process; exopod 7-segmented, with intersegmental articulation between segments 2 and 3 not completely expressed, with setal formula of $1,3,1,1,1,1,3$.

Mandible (Fig. 10C): well-developed coxal gnathobase, with a straight row of moderately incised teeth, ornamented with spinule rows on the medioventral part. Mandibular palp biramous; basis with four setae on inner margin. Exopod 5-segmented, with setal formula of 1, 1, 1, 1,2; endopod 2-segmented, proximal with four setae and distal segments with ten setae.

Maxillule (Fig. 10D): praecoxa and coxa incompletely fused; praecoxal arthrite with ten marginal spines plus four stiff setae on posterior surface, rows of tiny spinules on posterior surface. Coxal epipodite with nine setae; coxal endite with three stiff setae. Basis with cluster of denticles on the anterior surface; proximal basal endite with four setae; distal basal endite indistinct, with five setae; no trace of basal exite. Exopod with eleven marginal setae. A row of setules along the distal portion of the medial margin. Endopod not articulated to basis, indistinctly 3-segmented, setal formula 4, 4, 7.

Maxilla (Fig. 10E): apparently 6-segmented, comprising coalesced praecoxa and coxa, allobasis, and 3-segmented endopod. Armature of praecoxal and coxal endites $5,3,3,3$, respectively. Basal endite with four setae, one stouter than the rest; endopodal endite with one seta on tip. Free endopod setal formula 1, 1, 3, respectively. Integument of praecoxa ornamented with patch of spinules on the posterior margin. Prae- 


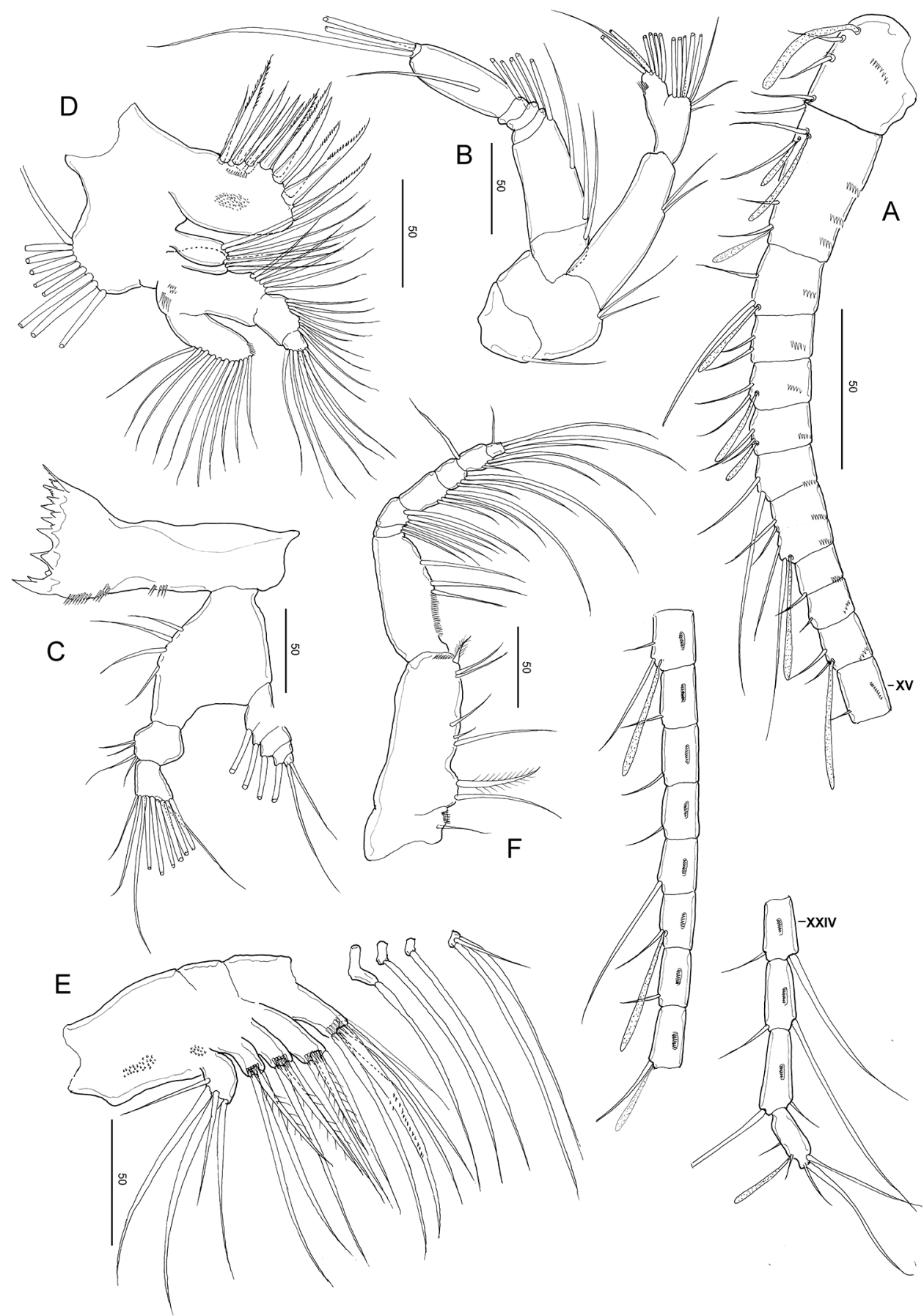

Figure 10. Stephos fortipes sp. nov. Female paratype $\mathbf{A}$ antennule $\mathbf{B}$ antenna $\mathbf{C}$ mandible $\mathbf{D}$ maxillule $\mathbf{E}$ maxilla $\mathbf{F}$ maxilliped. Scale bars in $\mu \mathrm{m}$. 
coxal and coxal endites with a cluster of long spinules subdistally on the lateral surface; distal coxal endite with an additional row of spinules proximally on the medial surface.

Maxilliped (Fig. 10F): syncoxa robust, with setal formula 1, 2, 2, 3 and an oblique row of tiny spinules on the posterior distal part; basis with three setae and a row of setules on the mediolateral margin; endopod six-segmented, with setal formula 2, 4, $4,3,3+1,4$.

Legs 1-4 (Fig. 11A-D), progressively larger towards posterior, each comprising coxa, basis, and 3-segmented exopod; endopod of leg 1 (Fig. 11A) 1-segmented, that of leg 2 (Fig. 11B) 2-segmented; endopods of leg 3 (Fig. 11C) and P4 (Fig. 11D) 3 -segmented. Armature formula of legs $1-4$ as in S. jejuensis sp. nov.

Leg 1 (Fig. 11A) biramous, coxa with hairs and spinules on the inner and posterior surfaces; basis with a row of spinules on the inner distal corner and long, curved inner setae, and endopod with a lobe on the outer margin, bearing a minute spinous process; second and distal exopodal segments with patched minute spinules; second and terminal exopodal segment with a row of spinules on the posterior margin.

Leg 2 (Fig. 11B) biramous, endopod 2-segmented; coxa with hairs on the inner margin, row of spinules on the posterior surface; basis unarmed; each first and second endopodal with row of spinules on the medial and distal edge, with pointed process on distolateral corner; exopod 3-segmented, with a row of spinules on the medio to distal margins of distal exopodal segment.

Legs 3 (Fig. 11C) and 4 (Fig. 11D) biramous, with 3-segmented rami: coxa with hairs on the inner margin and a row of spinules on the anterior surface; first to distal endopodal segments with a row of spinules on distal edges, with pointed process on each distolateral corner; exopod with a row of spinules on the medio to distal margins of distal exopodal segment.

Leg 5 (Fig. 11E) symmetric, uniramous, 3-segmented with proximal segment fused to intercoxal sclerite; basis separated from the single, tapering terminal segment. Second segment (basis) 1.38 times longer than wide $(44 \times 32 \mu \mathrm{m})$, with an anteromedial patch of minute spinules on the anterior surface. Distal segment constricted slightly at ca. mid-length with seven large spinules and inner stout spine and with two rows of denticles along the tapering portion

Male. Not collected.

Variations. Within this new species, there was a minor variation in the number of spinules on the genital double-somite and on the surfaces of legs 1-4 in the female.

Remarks. The new species closely resembles its congeners $S$. angulatus BradfordGrieve, 1999, S. hastatus, and S. pacificus Ohtsuka \& Hiromi, 1987; however, it differs in the following characteristics in the female: the antennule extends to the end of the genital double-somite (vs. first abdominal segment end in S. angulatus, and fifth pedigerous end in $S$. hastatus and $S$. pacificus); the operculum is slightly round (vs. triangular in three species); and the stout and present large row of spinules on the terminal tapering part of leg 5 (vs. not stout and absent in three species). 


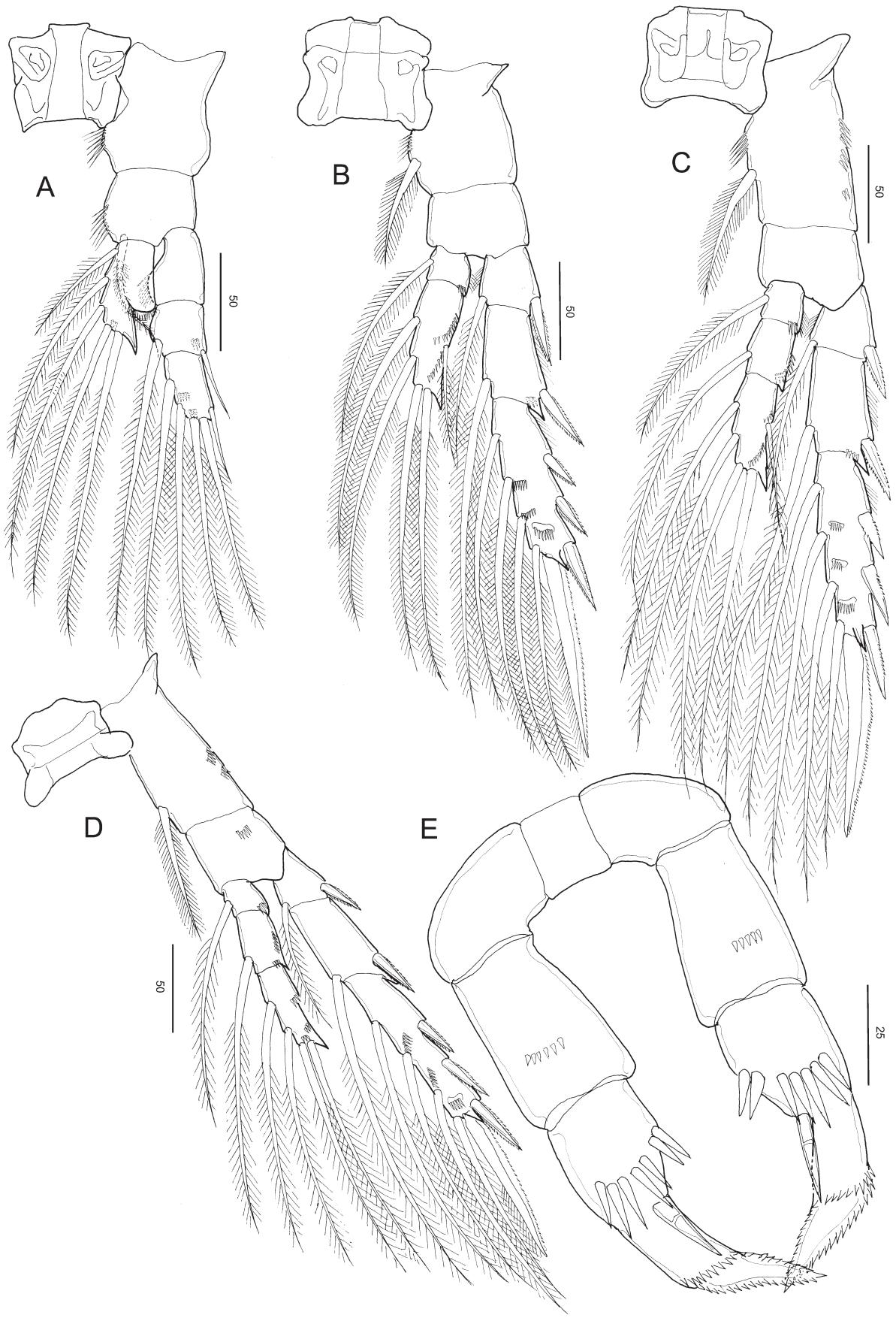

Figure II. Stephos fortipes sp. nov. Female paratype A leg 1 B leg 2 C leg 3 D leg 4 E leg 5, dorsal view. Scale bars in $\mu \mathrm{m}$. 


\section{Discussion}

The benthopelagic copepod fauna of the Korean peninsula was previously surveyed (Soh et al. 2013; Moon et al. 2014, 2015). They recorded five species: Sarsarietellus orientalis, Soh et al., 2013, offshore of Yogji and Maemul Island, southern Korea; Stephos geojinensis from the Geojin fishery port in eastern Korea; $S$. pacificus from the shallow waters of Jangdeong beach in southern Korea; S. projectus from the Naro Island in southern Korea; and Boholina ganghwaensis, Moon \& Soh, 2014, from Ganghwa Island in western Korea. The morphological characteristics of the genus Stephos, and a key to identifying the species were provided by Boxshall and Halsey (2004). Taxonomic analysis of closely related species of Stephos is based on the subtle morphological characters by Bradford-Grieve (1999) and Suárez-Morales et al. (2017). Bradford-Grieve (1999) categorized the species of the genus by analyzing the fourth segments of the male left fifth leg into four types. In this study, seven species in the Australian-Western Pacific region belong to "group IV", where the fourth segment of the male left fifth leg is narrow, as follows: S. angulatus Bradford-Grieve, 1999; S. geojinensis Moon, Youn, \& Venmathi Maran, 2015; S. jejuensis sp. nov., S. morii Greenwood, 1977; S. pacificus Ohtsuka \& Hiromi, 1987; S. pentacanthos Chen \& Zhang, 1965; and S. tsuyazakiensis Tanaka, 1967 (Table 1). The zoogeographic analysis presented based on the structural patterns of the female fifth leg by Suárez-Morales et al. (2017), grouped the 29 species of Stephos together. The three new species described here belong to "group A", where lateral setae are present and segments are apically elongate. This primitive "group A" is the most widespread, present in the most diverse regions (Suárez-Morales et al. 2017).

Most species of Stephos are frequently found in hyperbenthic and epibenthic habitats of tropical to polar regions (Boxshall and Halsey 2004; Jaume et al. 2008; Kršinić 2015; Moon et al. 2015; Suárez-Morales et al. 2017), and are occasionally recorded in anchialine caves (Boxshall et al. 1990; Riera et al. 1991; Carola and Razouls 1996; Jaume et al. 2008; Suárez-Morales et al. 2017). However, in this study, the three new species were collected at night using a plankton net in shallow waters. Other stephids have also occurred in plankton samples collected at night in coastal waters (Kos 1972; Ohtsuka and Hiromi 1987; Costanzo et al. 2000; Zagami et al. 2000; Moon et al. 2015). These facts suggest that benthopelagic calanoids could undertake daily vertical migrations (Zagami et al. 2000; Moon et al. 2015) and also diel feeding rhythm, reproduction, molting, dispersal, and niche diversification (Alldredge and King 1980).

The stephids comparisons of morphological features between the three new species of Korean fauna and the all species of genus Stephos are based on both sexes in the World. Stephos shares many of the characteristics of Miostephos Bowman, 1976, but differs in that the right fifth leg in female is 4-segmented and the male right fifth leg ends in an unarmed claw and/or mitten-like segment in Stephos (Boxshall and Halsey 2004; Kršinić 2015). According to Suárez-Morales et al. (2017), the structure of the female fifth leg is of great significance in the taxonomy of stephids. These characteristics were used in the keys to species of Stephos by Suárez-Morales et al. (2017). Here the following combination of features are used in order to separate 


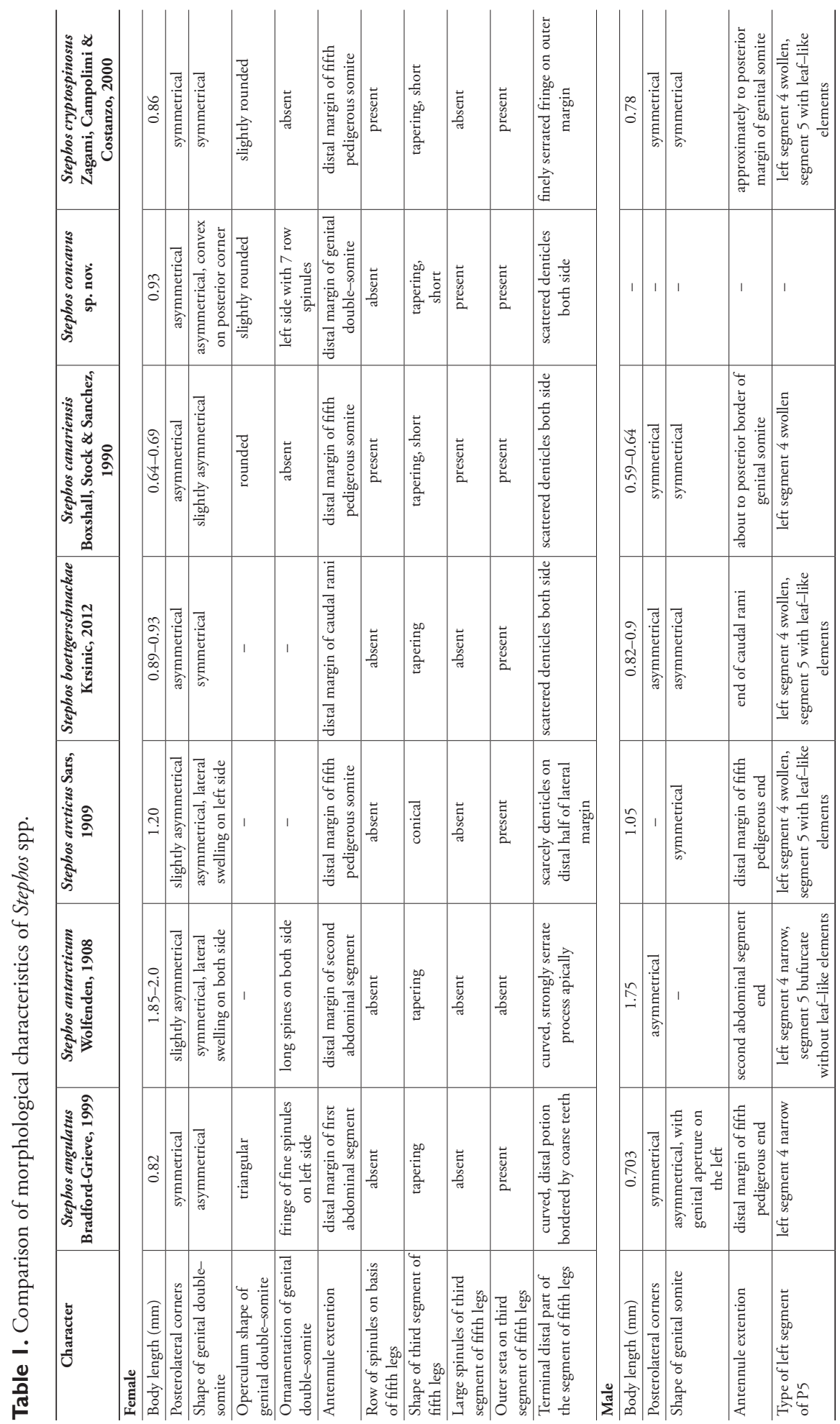




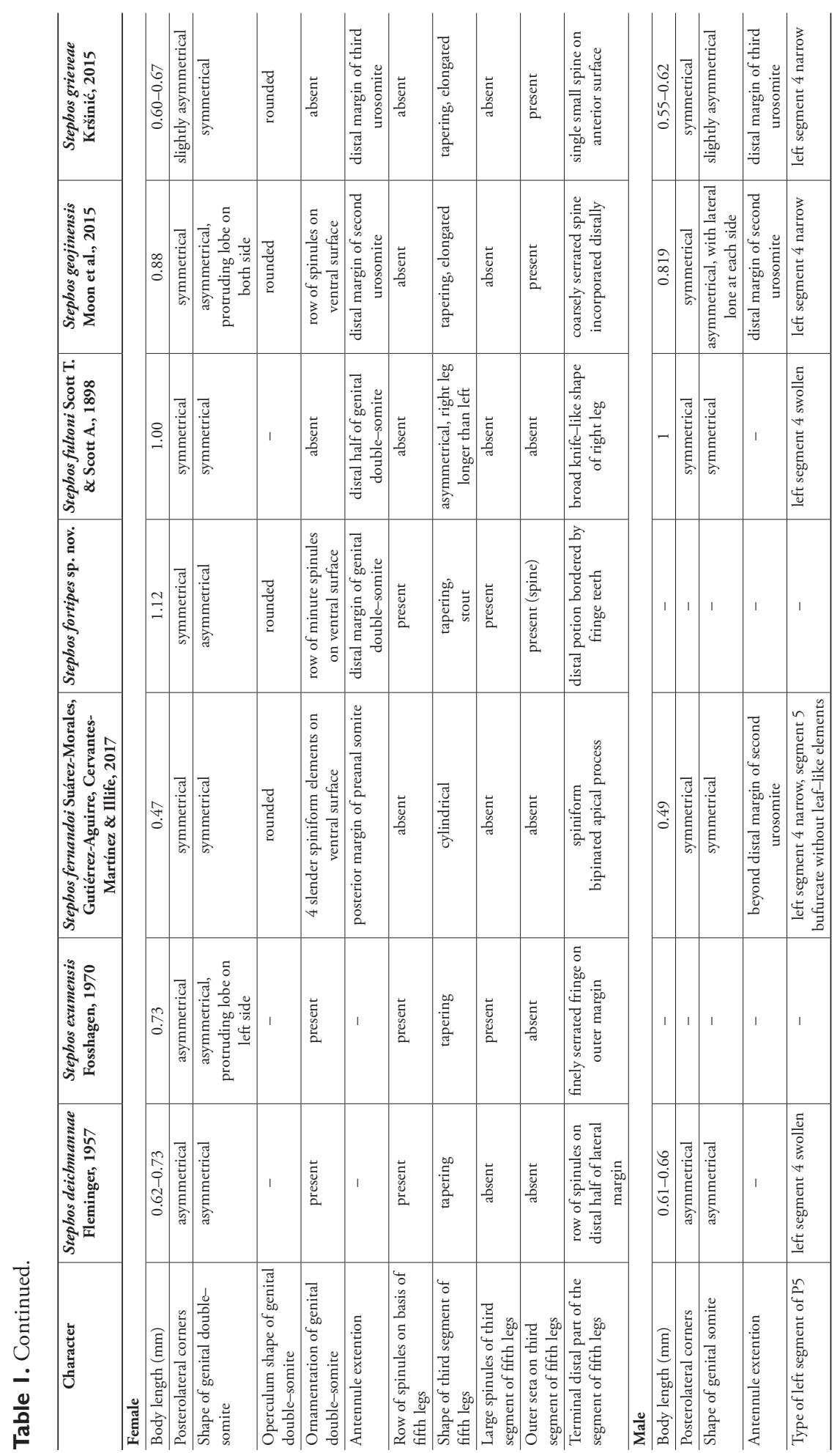




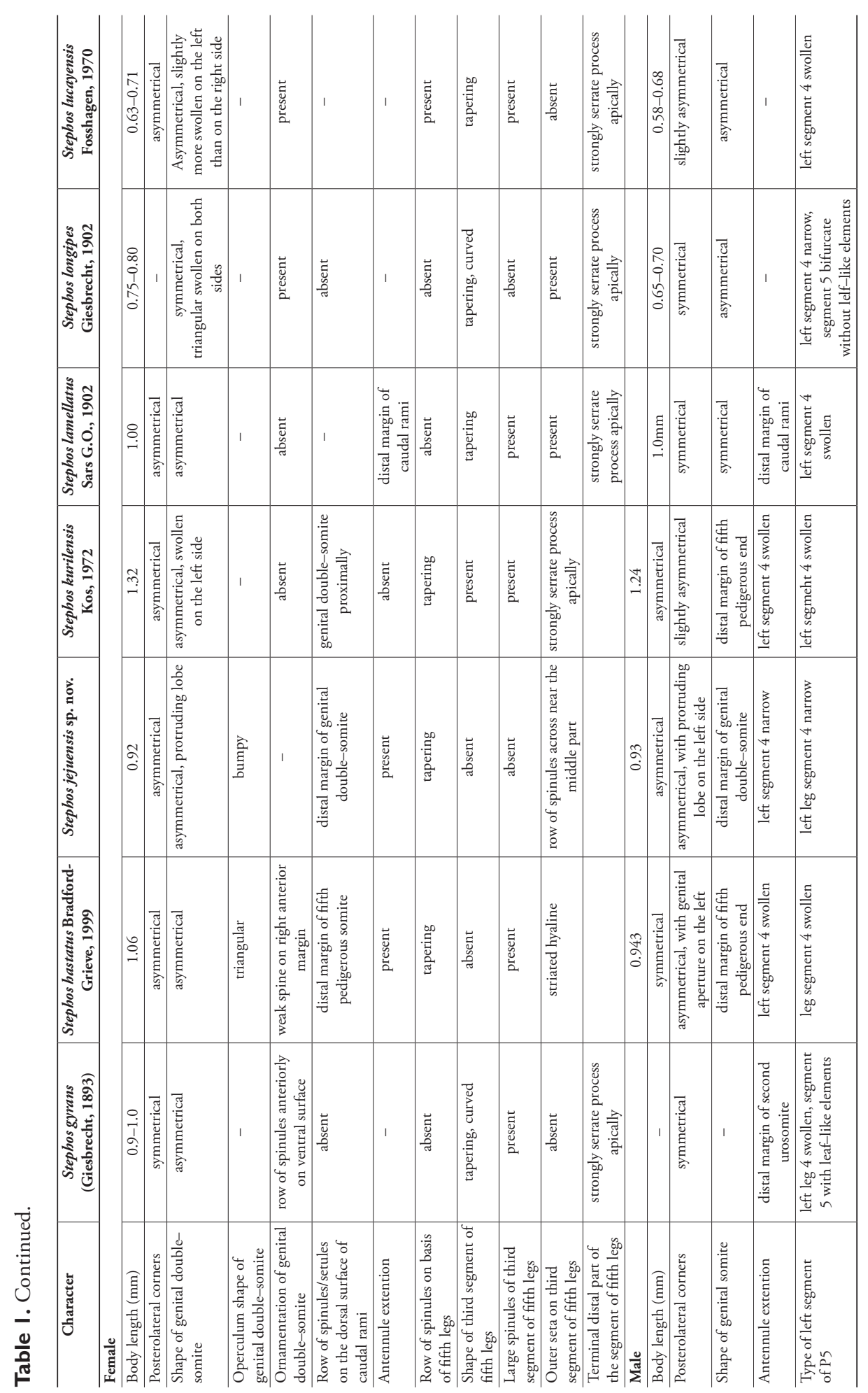




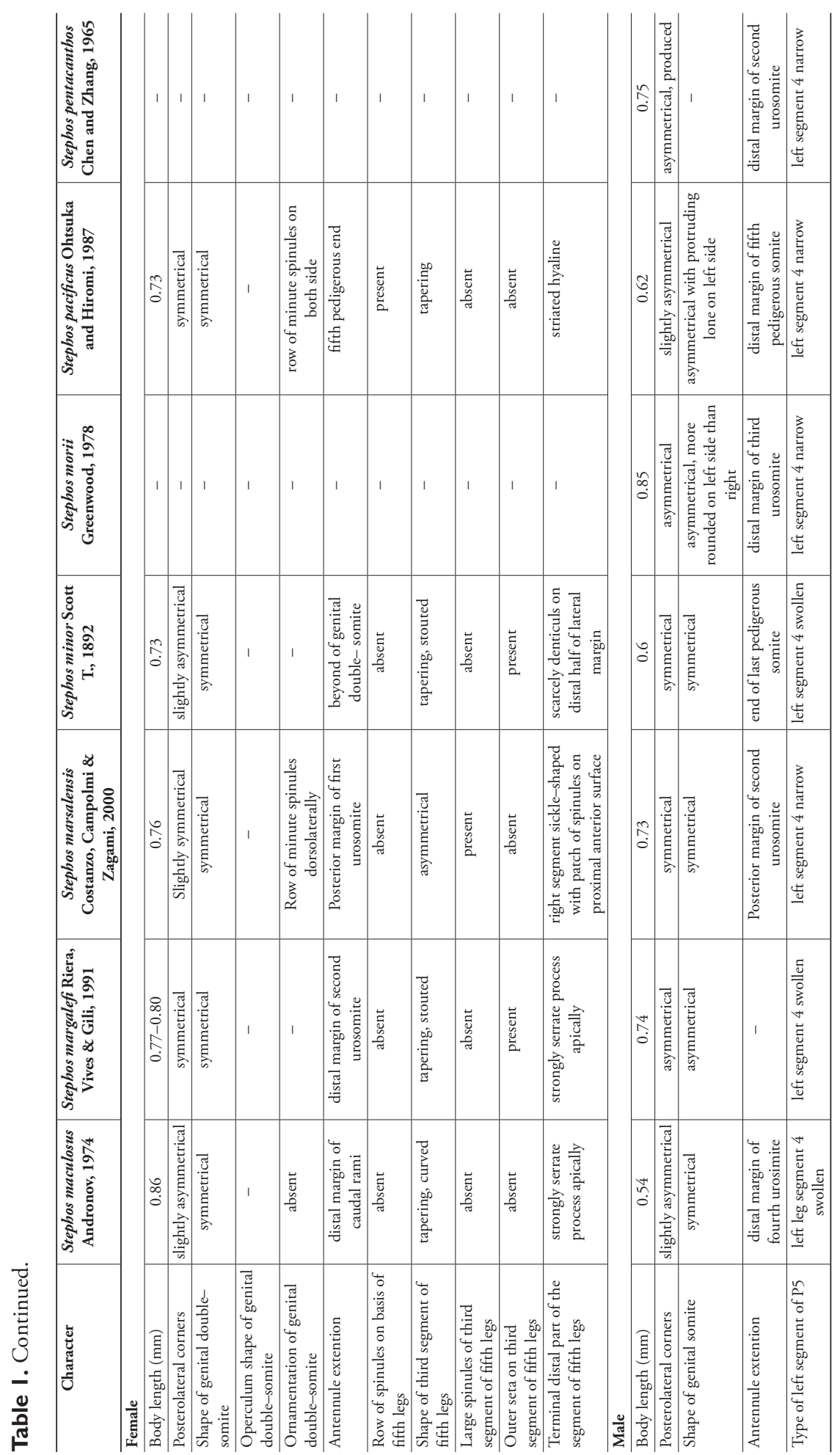




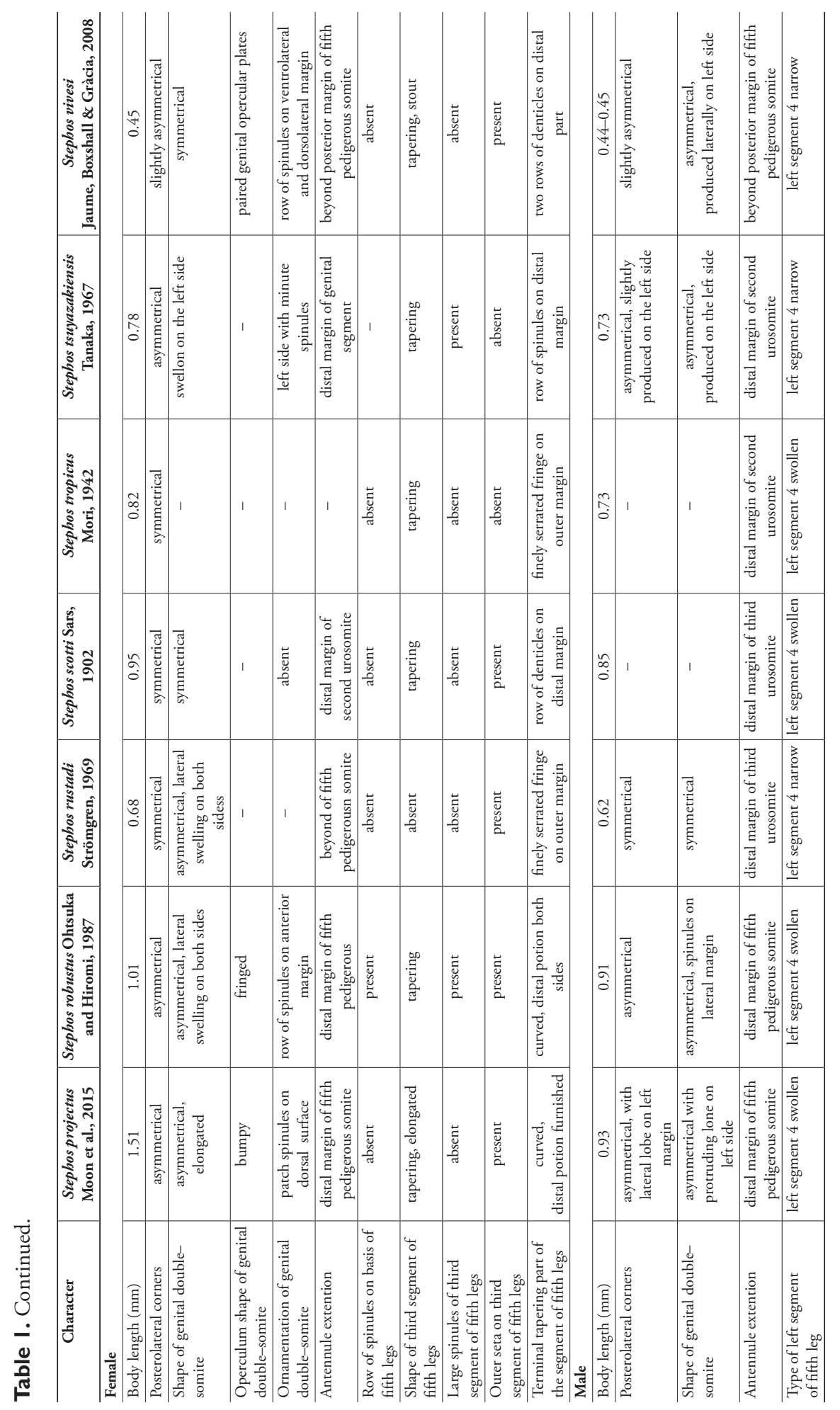


species: (1) the body length in both sexes; (2) the shape of postero-lateral corners in both sexes; (3) the shape and ornamentations of the genital double-somite in females; (4) the presence and/or absence of spinules on the caudal rami in both sexes; (5) the antennule extension in both sexes; and (6) the ornamentation and shape of fifth legs in both sexes.

The principal differences between the three new species and their congeners are summarized in Table 1. Although some features occasionally overlap within the all species considered herein, the characteristic combinations proposed are different for each species, showing them to be essential diagnostic elements. These morphological characteristics were very useful and important criteria for identifying each species of stephids.

To date, the genus Stephos consists of 35 valid species, including those described herein (Boxshall and Halsey 2004; Jaume et al. 2008; Kršinić 2012, 2015; Moon et al. 2015; Suárez-Morales et al. 2017; this study). Additionally, most of the genus Stephos species were not described following modern standards, and most of them need to be redescribed. Thus, the taxonomy, morphological variability, and distribution of stephids are well understood (Bradford-Grieve 1999; Moon et al. 2015; SuárezMorales et al. 2017). These facts suggest that more detailed research on its taxonomy, biodiversity, and molecular features is necessary for a better understanding of its evolutionary history.

\section{Acknowledgements}

This work was supported by a grant from the National Institute of Biological Resources (NIBR), funded by the Ministry of Environment (MOE) of the Republic of Korea (NIBR No. 2013-02-001) and a grant from National Institute of Fisheries Science (R2020028) of Korea

\section{References}

Alldredge AL, King JM (1980) Effects of moonlight on the vertical migration patterns of demersal zooplankton. Journal of Experimental Marine Biology and Ecology 44: 133-156. https://doi.org/10.1016/0022-0981(80)90150-1

Boxshall GA, Stock JH, Sánchez E (1990) A new species of Stephos Scott, 1892 (Copepoda: Calanoida) from an anchihaline lava pool on Lanzarote, Canary Islands. Stygologia 5: 33-41.

Boxshall GA, Halsey SH (2004) An Introduction to Copepod Diversity. Ray Society, London, 966 pp.

Bradford-Grieve J (1999) New species of benthopelagic copepods of the genus Stephos (Calanoida: Stephidae) from Wellington Harbour, New Zealand. New Zealand Journal of Marine Freshwater Research 33: 13-27. https://doi.org/10.1080/00288330.1999.9516853

Bradford-Grieve J (2004) Deep-sea benthopelagic calanoid copepods and their colonization of near-bottom environment. Zoological Studies 43: 276-291. 
Carola M, Razouls C (1996) Two new species of Calanoida from a marine cave of Minorca island, Mediterranean Sea: Stephos balearensis new species (Stephidae) and Paracyclopia gitana new species (Pseudocyclopiidae). Bulletin of Marine Science 58: 344-352.

Costanzo G, Campolmi M, Zagami G (2000) Stephos marsalensis new species (Copepoda, Calanoida, Stephidae) from coastal waters of Sicily, Italy. Journal of Plankton Research 22: 2007-2014. https://doi.org/10.1093/plankt/22.10.2007

Ferrari FD, Ivanenko VN (2008) The identity of protopodal segments and the ramus of maxilla 2 of copepods (Copepoda). Crustaceana 81: 823-835. https://doi. org/10.1163/156854008784771702

Giesbrecht W (1902) Copepoden. Resultats du Voyage du S.Y. Belgica en 1887-1889, Expedition Antarctique Beige. Rapports scientifique, zoologie, 1-49. [13 pls.]

Humes AG, Gooding RU (1964) A method for studying the external anatomy of copepods. Crustaceana 6: 238-240. https://doi.org/10.1163/156854064X00650

Huys R, Boxshall GA (1991) Copepod Evolution. The Ray Society, London, 468 pp.

Jaume D, Boxshall GA, Gràcia F (2008) Stephos (Copepoda: Calanoida: Stephidae) from Balearic caves (W Mediterranean). Systematics and Biodiversity 6: 503-520. https://doi. org/10.1017/S1477200008002764

Kos MS (1972) A new species of Stephos (Copepoda, Calanoida) from coastal waters of the Kuril Islands. Crustaceana 23: 113-118. https://doi.org/10.1163/156854072X00282

Kršinić F (2012) Description of Stephos boettgerschnackae sp. nov., a new copepod (Calanoida, Stephidae) from an anchialine cave in the Adriatic Sea. Crustaceana 85: 525-1539. https:// doi.org/10.1163/156854012X651718

Kršinić F (2015) Description of Stephos grieveae sp. nov. (Calanoida, Stephidae) from an anchialine cave in the Adriatic Sea. Marine Biodiversity Records 8: e125. https://doi.org/10.1017/ S1755267215001013

Moon SY, Soh HY (2014) A new species of Boholina (Copepoda, Calanoida, Boholinidae) from Ganghwa Island in western Korea. Journal of Marine Biological Association of the United Kingdom 94: 537-545. https://doi.org/10.1017/S002531541300177X

Moon SY, Youn SH, Soh HY (2015) Two new species of benthopelagic Stephos (Copepoda, Calanoida, Stephidae) from Korea. ZooKeys 495: 21-40. https://doi.org/10.3897/zookeys. 495.7862

Ohtsuka S, Hiromi J (1987) Calanoid copepods collected from the near-bottom in Tanabe Bay on the Pacific coast of the middle Honshu, Japan. III. Stephidae. Publications of the Seto Marine Biological Laboratory 32: 219-232. https://doi.org/10.5134/176144

Riera T, Vives F, Gili JM (1991) Stephos margalefi sp. nov. (Copepoda: Calanoida) from a submarine cave of Majorca Island (Western Mediterranean). Oecologia Aquatica 10: 317-323.

Soh HY, Moon SY (2014) Invertebrate Fauna of Korea (Vol. 21, No, 34). Arthropoda: Maxillipoda: Copepoda: Calanoida, Marine Planktonic Copepods III. National Institute of Biological Resources, 147 pp.

Soh HY, Moon SY, Ohtsuka S, Pae SJ, Jeong HK (2013) Reconstruction of arietellid copepod phylogenetic relationship, with description of a new species of Sarsarietellus (Copepoda, Calanoida, Arietellidae) from Korean waters. Zoological Science 30: 889-1004. https:// doi.org/10.2108/zsj.30.998 
Suárez-Morales E, Gutiérrez-Aguirre M, Cervantes-Martínez A, Illiffe TM (2017) A new anchialine Stephos Scott from the Yucatan Peninsula with notes on the biogeography and diversity of the genus (Copepoda, Calanoida, Stephidae). ZooKeys 671: 1-17. https://doi. org/10.3897/zookeys.671.12052

Zagami G, Campolmi M, Costanzo G (2000) A new species of Stephos T. Scott, 1892 (Copepoda: Calanoida) from coastal waters of Sicily, Italy. Journal of Plankton Research 22: 15-27. https://doi.org/10.1093/plankt/22.1.15 